\title{
RADIKALISME ISLAM DAN MOTIF TERORISME DI INDONESIA
}

\author{
Zulfadli \\ Universitas Andalas Padang \\ Jl. Universitas Andalas, Kota Padang, 25163, Indonesia \\ E-mail:zulfadli_fdl@yahoo.com
}

\begin{tabular}{l|l|l}
\hline Received: & Revised: & Approved: \\
16/03/2017 & $22 / 06 / 2017$ & $23 / 06 / 2017$ \\
\hline
\end{tabular}

\section{Abstrak}

Tulisan ini mengupas tentang fenomena radikalisme agama dan motif terorisme di Indonesia. Terorisme menjadi ancaman yang sangat serius dalam dinamika politik lokal, nasional dan internasional. Perang melawan terorisme sama halnya dengan perjuangan masa depan yang tidak berkesudahan. Membicarakan masalah terorisme, selalu dikaitkan dengan kelompok-kelompok radikal keagamaan. Begitu juga hal-hal yang berbau radikal selalu diidentikkan dengan kekerasan yang melibatkan agama di dalamnya. Fenomena terorisme yang melanda sebagian Negara, pelakunya senantiasa dipersepsikan sebagai kelompok radikal keagamaan. Lebih parah lagi banyak kalangan yang mencoba mengidentikkan terorisme dengan Islam. Penelitian ini munggunakan metode kualitatif dengan jenis penelitian kepustakaan (libary research), yaitu penelitian yang sumber datanya diperoleh dari buku-buku dan jurnal yang membahas terorisme. Penelitian ini mengidentifikasi motif terorisme di Indonesia yaitu motif politik, motif agama dan motif ideologi terorisme di Indonesia. Peneltian 
membuktikan bahwa rencana pembangunan Mall di sejumlah daerah, terjadinya jurang yang lebar antara orang kaya dan orang miskin, tidak terpenuhinya hak-hak masyarakat, orientasi pembangunan yang hanya mengedepankan aspek fisik, kurang memperhatikan aspek ruhani dan nilai-nilai sosial-keagamaan masyarakat, meluasnya kekerasan dan konflik merupakan faktor yang bisa menyuburkan terorisme

Kata kunci: motif, terorisme, dan agama

\section{Abstract}

This article analyzes about the phenomena of religious radicalism and motives of terrorism in Indonesia. Terrorism becomes a very serious threat in the dynamics of local, national and international politics. The fight against terrorism as well as the struggle for the future that never-ending. Discussing about terrorism issue is always related to radical religious groups. Likewise, the radicalism is always identic with religious violence. The phenomena of terrorism which happen in some countries, the perpetrators are often perceived as a radical religious group. Even many people attempt to equate terrorism with Islam. This study refers to qualitative method with library research, namely the research which the sources obtained from books and journals about terrorism. This study identify the motives of terrorism in Indonesia that are political, religious, and ideological motives of terrorism in Indonesia. The findings of the research show that the building plans in some places, big gap between rich and poor people, unfulfilled community rights, building orietation which focuses on physical aspects, not paying attention to spiritual aspects and religion and social values, the spread of violences and conflicts are some factors which can improve terrorism.

\section{Key words: motive, terrorism, religion}




\section{A. Pendahuluan}

Terorisme menjadi ancaman yang sangat nyata dalam konstelasi politik nasional, regional maupun internasional pada abad ke-21. Tak ada satu pun negara yang aman dari ancaman terorisme, apakah negara maju, maupun negara berkembang. Perubahan yang terjadi begitu intensif-massif dalam kehidupan masyarakat berimplikasi terhadap proses tranformasi dan perubahan konfiugurasi politik global. Di satu sisi muncul riak demokrasi yang menekankan nilainilai persamaan dan keadilan, sementara di sisi lain muncul gelombang ekonomi pasar yang sangat di dominasi oleh jingkrang kapitalisme.

Oleh karena itu terjadi pola perubahan perubahan politik dan ekonomi global yang menempatkan negara bangsa dalam posisi ketergantungangan (independensi) dan saling keterkaitan (interlinkage). Bersamaan dengan kondisi itu pula muncul lah aksi terorisme yang terjelma dalam bentuk aksi bom bunuh diri, radikalisme agama, menciptakan terror di masyarakat, bom buku dan lain sebagainya.

Sesungguhnya praktek terorisme telah berlangsung sejak lama. Hanya saja Istilah terorisme, menjadi wacana publik semenjak 11 september 2001 dengan runtuhnya dua menara kembar WTC di New York dan Pentagon di Washington. Peristiwa ini sangat mengerikan dan menghentakkan dunia. World Trade Centre ( WTC) dan Pentangon sebagai simbol perekonomian dan pertahanan Amerika Serikat musnah dalam serangan dahsyat tersebut. ${ }^{1}$

1 Rahul Mahajan, Perang Salib Baru: Amerika Melawan Terorisme atau Islam, trans. oleh Zaimul Am (Jakarta: Serambi Ilmu Semesta, 2002), 7. lihat juga sejarah terorisme dan fundamenatalisme agama-agama samawi, lihat; Karen Amstrong, Berperang Demi Tuhan, Fundamentalisme, dalam Islam, Kristen dan Yahudi (Jakarta: Serambi Ilmu Semesta, 2002). 
Terorisme adalah suatu istilah yang mengandung keekaburan dan sering disalah tafsirkan. Apalagi, istilah terorisme dihubungkan dengan ideologi politik tertentu. Upaya untuk mendefinisikan istilah terorisme biasanya didasarkan atas asumsi, bahwa setiap tindakan kekerasan, terutama kekerasan politik (political violence) adalah justifiable sementara kekerasan dalam bentuk lain adalah unjustifiable. Kekerasan bentuk kedua ini yang tergolong teror. ${ }^{2}$

Osama bin Laden ${ }^{3}$ dengan jaringan Al-Qaedanya satusatunya yang tertuduh dan harus bertanggung jawab dalam peristiwa tersebut. Kesimpulan ini dipegang oleh pemerintah Amerika Serikat tanpa mengikutsertakan buktibukti terlebih dahulu. Koalisi internasional anti terorisme segara dibentuk. Dunia harus mengikuti Amerika Serikat dalam perang melawan terorisme. Dunia dipaksa memilih antara "carrot" atau "stick". Negara yang membantu Amerika dalam perang melawan terorisme akan diberi bantuan, adapun Negara yang enggan tunduk terhadap keinginan Amerika akan digebuk dan dituduh teroris. Rezim yang tidak mau melawan terorisme akan dicap sebagai rezim jahad (hostile regime). ${ }^{4}$

2 Azyumardi Azra, Pergolakan politik Islam: Dari fundamentalisme, modernisme hingga post-modernisme (Jakarta: Paramadina, 1996), 143.

3 "Osama dilahirkan di Arab Saudi pada tahun 1957. Dia anak seorang kontraktor kaya raya berkebangsaan Arab. Saat pecah perang Afganistan (1979-1989) dia menjadi sukarelawan di bidang logistik. Dia juga pernah dididik di agen resmi Amerika Serikat (CIA) di bawah bimbingan Mike Schuer.,".

${ }^{4}$ Negara-negara Muslim tertentu yang oleh Amerika Serikat dituding sebagai pendukung terorisme adalah; Irak, Somalia, Sudan, Suriah dan Iran. Adapun kelompok-kelompok organisasi Islam seperti Islamic Jihad, Hamas, dan Hisbullah dinyatakan sebagai sasaran perang melawan terorisme. Amerika Juga 
Terorisme dan bom bunuh diri di Indonesia menjadi polemik dan mengundang wacana. Tokoh agama, pejabat militer, Polri, cendikiawan, politisi dan tokoh-tokoh LSM angkat bicara tentang terorisme. Dari forum mahasiswa di kampus sampai pada konferensi internasional diadakan untuk mencari definisi terorisme dan latar belakang politik yang memotivasinya.

Agama sering menjadi bahan amunisi dalam setiap aksi terorisme. Setiap agama sangat mengutuk terhadap tindakan terorisme. Agama sangat jauh dan bahkan sangat berbeda dari dari tindakan terorisme. Namun semua peristiwa kekerasan terorisme yang terjadi di tanah air tidak begitu saja bisa dipisahkan dari pemahamanpemahaman keagamaan yang skripturalis, berpikir sempit, jumud, eksklusif, yang pada gilirannya melahirkan ideologi radikalisme.

Penafsiran agama untuk melakukan kekerasan yang dilandasi oleh semangat keagamaan merupakan pengingkaran terhadap ajaran agama yang sesungguhnya. Penafsiran yang sempit, serba parsial, yang dijadikan legitimasi dalam melakukan teror untuk menebarkan rasa takut dan khawatir kepada orang lain atau kelompok tertentu yang dinamakan terorisme agama (religious terrorism).

Oleh karena itu terorisme agama (relegious terrorisme) berbeda dengan teror yang dilakukan oleh negara (state terrorism). Terorisme agama merupakan tindakan teorisme yang berbasis pada nilai-nilai keagamaan, yang cenderung disalah tafsirkan, direduksi, dan disalahgunakan untuk melakukan tindakan teror. Sementara terorisme negara

mengumumkan Negara-negara non-Muslism seperti Kuba dan Korea Utara sebagai Negara teroris. Lihat Chandra Muzaffar, Muslim, dialog, dan teror (Jakarta: Profetik, 2003), 187. 
adalah terorisme yang dilakukan oleh penguasa untuk melakukan teror terhadap warganya. ${ }^{5}$

Ketika agama menjadi justifikasi tindakan-tindakan teror, apakah hal ini dapat digunakan untuk tujuan-tujuan politik? Pertanyaan ini tidak gampang dijawab, dikarenakan terorisme mengandung kompleksitas dalam dirinya. Ia terkait dengan berbagai ragam ideologi politik dunia yang mengitarinya. Azyumardi Azra melihat kompeksitas radikalisme dan terorisme bersifat internal dan eksternal. ${ }^{6}$ Gerakan terorisme memiliki basis ideologi, pemikiran dan strategi gerakan yang berbeda dengan ormas-ormas Islam yang ada sebelumnya. Mereka ditengarai berhaluan puritan, memiliki karakter yang lebih militan, skripturalis, konservatif dan eksklusif.

Semua peristiwa aksi pengeboman menjadi babakan baru dari wajah politik Indonesia. Negeri yang terkenal ramah, aman dan beradab, serta merta pupus akibat tindakan kekerasan terorisme. Oleh kalangan internasional Indonesia dinyatakan sebagai salah satu sarang dari terorime di Asia Tenggara. Dunia dipaksa memilih antara "carrot" atau "stick". Negara yang membantu Amerika dalam perang melawan terorisme akan diberi bantuan, adapun Negara yang enggan tunduk terhadap keinginan Amerika akan digebuk dan dituduh teroris. ${ }^{7}$ Rezim yang

${ }^{5}$ Mark Juergensmeyer, Terorisme Para Pembela Agama, trans. oleh Amien Rozany Pane (Yogyakarta: Tarawang Press, 2003), 56.

${ }^{6}$ Azyumardi Azra, "Gerakan Islam Militan di Asia Tenggara: Identitas atau Tantangan," Jurnal CSIS Vol. 33, no. 1 (Maret 2014): 96-97.

${ }^{7}$ Negara-negara Muslim tertentu yang oleh Amerika Serikat dituding sebagai pendukung terorisme adalah; Irak, Somalia, Sudan, Suriah dan Iran. Adapun kelompok-kelompok organisasi Islam seperti Islamic Jihad, Hamas, dan Hisbullah dinyatakan sebagai sasaran perang melawan terorisme. Amerika Juga 
tidak mau melawan terorisme akan dicap sebagai rezim jahad (hostile regime). Terorisme dan bom bunuh diri di Indonesia menjadi polemik dan mengundang wacana. Berbagai upaya yang telak dilakukan pemerintah dalam menangkal terjadinya terorisme tak kunjung menghentikan praktek terorisme. Mulai dari membentuk Densus 88 dan Badan Nasional Penanggulangan Terorisme (BNPT) dan perangkat hukum Undang-Undnag No 15 tahun 2003 tentang Pemberantasan Tindak Pidana Terorisme.

Namun kenyataannya ideologi terorisme tidak tidak pernah surut terjadi di Indonesia. Dalam melakukan penindakan dan pencegahan terhadap gerakan terorisme maka perlu diketahui tentang motiv-motiv terorisme yang terjadi di Indonesia dan kaitannya dengan radikalime agama. Dengan demikian identifikasi dan pemetaan terhadap motiv terorisme dan radikalisme agama dapat dijadikan dasar dalam melakuan pencegahan dan penindakan terhadap praktek terorisme yang terjadi di Indonesia.

Tulisan ini membahas tentang fenomena radikalisme agama dan motif terorisme di Indonesia. Ibarat dua sisi dari sekeping mata uang, terorisme dan radikalisme merupakan dua konsep yang berbeda akan tetapi tidak bisa dipisahkan antara yag satu dengan yang lainnya. Penelitian ini menggunakan metode kualitatif dengan jenis penelitian ini kepustakaan (library reseach), yaitu penelitian yang sumber datanya diperoleh dari buku-buku yang membahas terorisme, jurnal dan data yang dihimpun dari media massa. Penelitian ini bersifat deskriptik analitik, yaitu dengan mendeskripsikan definisi dan posisi terorisme,

mengumumkan Negara-negara non-Muslism seperti Kuba dan Korea Utara sebagai Negara teroris. Lihat Muzaffar, Muslim, dialog, dan teror, 187. 
selain itu juga menguraikan radikalisme agama dan motiv terorisme yang terjadi di Indonesia.

\section{B. Terorisme dan Radikalisme Islam di Indonesia}

Radikalisme dan terorisme merupakan istilah yang relatif baru dalam diskursus politik. Para ilmuwan politik baik dari kalangan Muslim maupun non-Muslim berusaha memberikan definisi dan penafsiran masing-masing tentang fenomena ini. Radikalisme dipahami sebagai sikap batin yang mencerminkan keyakinan tentang suatu kebenaran yang kadang sulit dimengerti. Keyakinan tentang suatu "yang benar" ini, membuat para penganutnya berkeinginan untuk merealisasikannya dalam segala aspek kehidupan, di mana kehidupan dijalankan sesuai dengan "yang benar" tersebut.

Biasanya radikalisme selalu dikaitkan dengan ideologi politik yang memperjuangkan perubahan mendasar dari suatu tatanan atau sistem, seperti sistem ekonomi, politik, sosial, budaya dan pendidikan serta aspek kehidupan yang lainnya. Sebagai sebuah ideologi atau paham politik, radikalisme memuat seperangkat ide atau gagasan tentang bentuk masyarakat dan Negara, radikalisme juga memuat strategi dan taktik untuk mewujudkan ide atau gagasan tersebut. Selain itu radikalisme menuntut kesungguhan para penganutnya demi mencapai tujuan politiknya.

Membicarakan masalah terorisme, selalu dikaitkan dengan kelompok-kelompok radikal keagamaan. Begitu juga hal-hal yang berbau radikal selalu diidentikkan dengan kekerasan yang melibatkan agama di dalamnya. Fenomena terorisme yang melanda sebagian Negara, pelakunya senantiasa dipersepsikan sebagai kelompok radikal keagamaan. Setidaknya demikian pandangan para analis Barat tentang fenomena terorisme dan radikalisme yang sedang melanda dunia saat ini. Lebih parah lagi 
banyak kalangan yang mencoba mengidentikkan terorisme dengan Islam.

Di Indonesia, fenomena terorisme tumbuh dan berakar dari ideologi radikalisme anasir-anasir gerakan DI/TII. Gerakan yang dipimpin oleh Sekarmadji Maridjan Kartosoewiryo $^{8}$ ini terobsesi untuk mendirikan Negara Islam Indonesia (NII). Adalah tujuh kata dalam Piagam Jakarta yang menjadi memicu munculnya gerakan DI/TII. Seperti diketahui dalam sejarah awal kemerdekaan Indonesia, terjadi perselisihan antara kelompok nasionalis sekuler dengan kelompok nasionalis Islam mengenai dasar Negara Indonesia.

Kalangan nasionalis Islam menuntut dan memperjuangkan Islam sebagai dasar Negara yang baru merdeka. Namun karena alasan persatuan nasional, Piagam Jakarta yang telah ditanda tangani pada tanggal 22 Juni 1945 dikoreksi kembali. Dengan alasan persatuan nasional maka tujuh kata dalam Piagam Jakarta yang sangat berarti terhadap kalangan nasionalis Islam dihapus. ${ }^{9}$ Kekalahan dan kekecewaan politik kalangan nasionalis Islam ini, membuat Kartosoewiryo tidak hanya berseberangan dengan Negara yang dianggapnya telah dikuasi oleh kaum sekuler, tetapi lebih dari itu ia mencita-citakan berdirinya Negara Islam Indonesia (NII).

8 "S.M. Kartosoewiryo dilahirkan di Cepu pada tanggal 7 Januari 1905. Ia seorang Muslim garis keras yang mendedikasikan hidupnya untuk lahirnya NII. Ia aktif di Sarekat Islam (SI) dan Jong Islamieten Bond (JIB) serta di partai Masyumi. Aktifitasnya di tiga organisasi inilah yang membuatnya bertemu dengan $\mathrm{H}$. Agoes Salim, Tjokroaminoto dan Muhammad Natsir. Pertemuan dengan tiga tokoh SI dan Masyumi ini sangat berpengaruh bagi pandangan dan orientasi politik Kartosoewiryo,"

${ }^{9}$ Lugman Hakim, Terorisme di Indonesia (Surakarta: Forum Studi Islam Surakarta, 2004), 31. 
Walaupun gerakan DI/TII dapat dipatahkan oleh pemerintah Indonesia dengan tertangkapnya Kartosoewiryo pada tahun 1962, namun gerakan ini telah terlanjur mendapat simpati dan dukungan dari sebagian kalangan umat Islam di Indonesia. Para aktivis dan simpatisan DI/TII yang tidak tertangkap dengan berbagai variannya menjadi cikal bakal dari radikalisme di Tanah Air Indonesia.

Salah seorang dari aktivis DI/TII yang melanjutkan perjuangan Kartosoewiryo adalah Ajengan Masduki yang bersama-sama Ustadz Abdullah Sungkar dan Ustadz Abu Bakar Ba'asyir mendirikan dan membesarkan al-Jama'ah alIslamiyyah (JI). ${ }^{10}$

Abdullah Sungkar dibantu Ajengan Masduki dan Abu Bakar Ba'asyir berhasil mengembangkan JI menjadi gerakan bawah tanah yang mampu membangun simpul-simpul organisasi dan sel-sel gerakan untuk menegakkan Syari'ah Islam dan kepentingan pendirian Daulah Islamiyyah.

Gagasan tentang Daulah Islamiyyah merupakan alat perekat dan Master Plan dari sel-sel gerakan al-Jama'ah alIslamiyyah. Sebagian dari organisasi yang mempunyai kesamaan ideologis dan politis dengan al-Jama'ah alIslamiyyah adalah Majelis Mujahidin Indonesia (MMI) ${ }^{11} \mathrm{dan}$

10 A. Maftuh Abegebriel, "'Ada Apa Dengan Dokumen JI? Sebuah Penghampiran Hermeneutik,"' in Negara Tuhan The Thematic Encyclopaedia, ed. oleh A. Maftuh Abegebriel (Jogjakarta: SR-Ins Publishing, 2004), 910 dalam.

${ }^{11}$ MMI didirikan di Jogjakarta pada bulan Agustus tahun 2000 melalui pertemuan aktivis Islam dari berbagai daerah di Indosesia. Dalam pertemuan ini Abu Bakar Ba'asyir terpilih menjadi Amir MMI dan Irvan S. Awwas terpilih menjadi ketua dewan legislatif (Lajnah Tanfidziyah). Muhammad Ahmad Assegaf, "MMI dan HTI; The Image of The Others" ibid., 693. 
Hisbut Tahrir Indonesia (HTI)). ${ }^{12}$ Kesamaan ideologi dan tujuan politik MMI dan HTI merupakan benang merah yang menghubungkan MMI dan HTI dengan al-Jama'ah alIslamiyyah. Atau setidaknya antara tiga organisasi Fundamentalis Radikal Islam ini membentuk strategi aliansi untuk proyek Daulah Islamiyyah dan Khilafah Establishing yang meliputi Indonesia, Malasyia, Thailand selatan, Filipina selatan dan Singapura.

Di tanah air Indonesia, organisasi-organisasi Islam radikal lainnya yang sering menjadikan agama sebagai justifikasi dari tindakan-tindakan mereka adalah Front Pembela Islam (FPI) ${ }^{13}$ pimpinan Habib Rizhiq, Laskar Jihad ${ }^{14}$ pimpinan Jakfar Umar Thalib dan Laskar Jundullah

12 “Tentang HTI dan pengaruh ideologi HTI dapat ditelusuri sejak Taqiyudin al-Nabhani mengunjungi Indonesia pada tahun 1972. al-Nabhani adalah tokoh Islam dari Palestina dan sekaligus pendiri Hizbut Tahrir (HT) pada tahun 1953 di Yerussalem. Hizbut Tahrir (HT) berbasis di Yordania dan Lebanon.,"

13 "Front Pembela Islam (FPI) dikenal sangat dengan kalangan militer. Kedekatan FPI dengan militer dapat dilihat dari pembelaan mereka terhadap para jendral-seperti Wiranto- yang diduga melakukan pelanggaran HAM di Timor-Timur. Ratusan anggota FPI menyerang para demonstran yang menuntut agar para jendral tersebut segera diadili. FPI juga menyerang kantor Komisi Nasional Hak Azasi Manusia (KOMNAS HAM) di Jakarta.,"

14 "Organisasi ini sering mengirimkan anggotanya untuk berjihad ke Poso dan Ambon. Jakfar Umar Thalib sendiri adalah alumni Pondok Pesantren PERSIS di Pasuruan Jawa Timur. PERSIS adalah organisasi yang secara radikal memperjuangkan kepentingan-kepentingan Islam. Umar Thalib pernah belajar di Pakistan dan alumni perang Afghanistan. Di Afghanistan inilah, Umar Thalib disinyalir menjalin hubungan dengan Osama bin Laden dan Umar al-Faruq.," 
pimpinan Agus Dwikarna15 dan Laskar Mujahidin. Anggota organisasi-organisasi ini adalah mereka eks perang Afghanistan.

Keberadaan organisasi-organisasi Islam Radikal yang telah disebut dimuka muncul seiring tumbangnya Orde Baru pada tahun 1998 oleh gerakan Mahasiswa. Runtuhnya tatanan politik refresif Orde Baru, oleh sebagian kalangan Muslim Indonesia dijadikan angin segar untuk merapatkan barisan kembali dan melakukan konsolidasi kekuatankekuatan yang tersebar di berbagai daerah.

Seperti diketahui, di masa Orde Baru terjadi proses marjinalisasi dan pengebirian yang dilakukan Negara terhadap Umat Islam di Indonesia. Oleh Orde-Baru Islam dilihat sebagai tantangan potensial yang dianggap membahayakan kepentingan politiknya. Akibat dari prilaku Negara yang tidak menguntungkan bahkan cenderung memusuhi ini, membuat Umat Islam tertekan secara politik. Kondisi ketertekanan politik dibawah rezim Orde-Baru inilah sebagai salah satu penyebab timbulnya sikap radikal sebagian Umat Islam Indonesia.

Untuk menjalankan politik refresif dan koersifnya terutama ditujukan kepada Umat Islam, Orde-Baru menjalankan aksi politik "penyeragaman berpikir" melalui proses deideologisasi dan depolitisasi. Orde-Baru

15 Agus Dwikarna dikenal mempunyai hubungan yang mesra dengan Umar al-Faruq, seorang yang disebut-sebut agen al-Qaidah di Asia Tenggara. Pada tahun 2001, Agus mengirimkan anggota Laskar Jundullah ke Afghanistan untuk berlatih merakit bom dengan bantuan al-Faruq. Kedua anggota Laskar Jundullah ini kemudian dikirim ke Moro Filipina. Tokoh-tokoh laskar Jundullah yang juga dikenal dekat dengan al-Faruq adalah Mukhtar Daeng Lau, wakil panglima Laskat Jundullah, Abu Zamiah dan Hizbullah Rasyid yang membantu al-Faruq membuat KTP Makasar dan Paspor Indonesia. Hakim, Terorisme di Indonesia, 67-68. 
mempunyai dua elemen alat pemaksa untuk memuluskan "penyeragaman berpikir" ala Orde-Baru ini, yaitu; refresive state apparatus dan ideological state apparatus. Penyeragaman ini bisa dilihat dari upaya Orde Baru dalam memaksa berbagai Parpol-parpol agar bergabung ke dalam tiga Parpol (Golkar, PPP dan PDI) yang disetujui Orde-Baru.

Wujud lain dari penyeragaman berpikir yang dilakukan Orde-Baru adalah pemaksaan agar menjadikan Pancasila sebagai satu-satunya ideologi dari berbagai organisasi politik maupun organisasi kemasyarakatan. Dikalangan Umat Islam sendiri terjadi perdedatan panjang tentang hal ini. Adalah Muhammadiyyah dan Nahdhatul Ulama, dua organisasi Islam terbesar yang dengan terus terang menerima dan menjadikan Pancasila sebagai ideologi resmi organisasi. Walau demikian, banyak kalangan atau kelompok Muslim tertentu yang secara terang-terangan atau sembunyi-sembunyi menolak Pancasila sebagai ideologi. Kelompok ini yang kemudian berkembang menjadi radikal serta mengembangkan radikalisme Islam di Indonesia.

Kelompok dan tokoh-tokoh Islam yang secara terangterangan menentang pemaksaan penyeragaman ideologi dan politik ala Orde Baru adalah Ustadz Abdullah sungkar dan Ustadz Abu Bakar Ba'asyir yang dikenal sebagai pemimpin al-Jama'ah al-Islamiyyah. Akibat tekanan pemerintah, kelompok ini kemudian berkembang menjadi organisasi bawah tanah yang oleh Amerika dan aparat intelijen Indonesia disebut al-Jama'ah al Islamiyyah. Ustadz Abdullah sungkar sendiri, bersama Ustadz Abu Bakar Ba' asyir, kabur ke Malaysia pada bulan April 1985.

Marjinalisasi dan diskriminasi yang dialami oleh Umat Islam Indonesia-baik yang moderat maupun yang radikalpada pemerintahan Orde Baru membuat kelompok yang disebut terakhir harus berhadapan dengan Negara. Kondisi refresif yang dialami sebagian kalangan Muslim di 
Indonesia, yang diakibatkan oleh Negara, sekarang diperparah oleh kondisi Umat Islam di Afganistan, Palestina, Somalia, Irak dan Negara-negara Muslim lainnya yang mengalami ketertindasan dan pembantaian oleh agresi politik Amerika Serikat dan Israel. Beberapa hal yang telah disebut diatas merupakan sebagian motif dari aksi "terorisme" di Indonesia.

Biasanya dalam praktik politik sehari-hari maupun hasil kajian ilmiah Sarjana-sarjana Barat, ketiga istilah tersebut sering dikaitkan dengan kelompok Islam politik. ${ }^{16}$ Dikalangan masyarakat Barat istilah fundamentalisme mulai terkenal semenjak meletusnya Revolusi Islam Iran tahun 1979 yang berhasil menumbangkan rezim Syah Pahlevi dukungan Amerika Serikat. Revolusi ini mengantarkan Ayatullah Khomeni membentuk Republik Islam Iran yang mempermaklumkan diri sebagai lawan dari the great Satan, Amerika Serikat.

Sebenarnya fundamentalisasi agama dan radikalisasi politik telah muncul jauh sebelum revolusi Iran meletus. Fenomena ini tampil dalam panggung politik disebabkan dua faktor penting, yaitu; pertama keadaan umat Islam yang mengalami kemiskinan di bidang ekonomi, keterbelakangan di bidang pendidikan dan ketertindasan dalam bidang politik dan lain sebagainya. Kedua, penetrasi kekuasaan politik Barat ke wilayah Islam. Kemunduran dan keterbelakangan umat Islam ini diperparah oleh semakin terdesaknya umat Islam oleh kolonisasi yang dilakukan Barat. Selain itu, yang memunculkan sikap fanatik dan militan umat Islam adalah aksi politik Amerika Serikat di

16 “Dalam kajian ilmu sosial politik, Islam politik dipahami sebagai kelompok politik Islam militan yang mendasarkan perjuangannya kepada keyakinan universalisme Islam. Keyakinan ini menuntut ditegakkannya nilai-nilai Islam dalam setiap aspek kehidupan manusia, termasuk tata Negara," 
Arab Saudi, Palestina, Afganistan dan Irak yang dianggap merugikan umat Islam.

\section{Motif-Motif Terorisme di Indonesia}

Terorisme telah menjadi fakta paling mengerikan sekaligus menggentarkan. Karena itu perlu pelacakan serius atas motif yang melatarbelakangi dan memotivasi tindakan terorisme. Yang dimaksud dengan motif, bukan hanya bersifat jangka pendek, tetapi jangka panjang. Motif berhubungan erat dengan masa lalu, keadaan sekarang dan harapan di masa depan. Pelacakan jauh ke belakang dan ke depan akan sangat diperlukan untuk mengetahui pelbagai kemungkinan yang mengindikasikan terorisme.

Menurut pandangan beberapa ahli yang mempunyai perhatian terhadap fenomena terorisme akhir-akhir ini menyatakan bahwa secara umum penyebab atau motif dari terorisme adalah ketiadakadilan, kemiskinan, keterbelakangan dan ketertindasan sebagian kelompok masyarakat di suatu negara. Ketidakadilan, kemiskinan dan keterbelakangan yang terjadi di sebagian Negara, terutama Negara-negara Muslim disebabkan oleh ulah imperialisme global dengan baju new-liberalisme yang memberikan kontribusi terhadap lahirnya fenomena terorisme. ${ }^{17}$

Menurut Jawahir Thontowi, terorisme tidak akan bisa ditanggulangi, apabila akar-akar persoalan ketidakadilan struktural, ekonomi, politik dan hukum secara global tidak diperbaiki. ${ }^{18}$

Earl Conteh-Morgan membentangkan sejumlah motif yang bisa memproduksi terorisme. Pertama, arus modernisasi dan urbanisasi. Fenomena globalisasi yang

17 Jawahir Thontowi, Islam Neo-Imperialisme dan Terorisme Perspektif Hukum Internasional dan Nasional (Jogjakarta: UII Press, 2004), 50-53.

18 Ibid., 58. 
memberi fasilitas untuk mengakses ilmu pengetahuan secara terbuka, bebas, dan murah memungkinkan siapa pun mempelajariteknik-teknik melakukan teror. Akses komunikasi yang difasilitasi kecanggihan teknologi mutakhir mempermudah dan mempercepat komunikasi antarjaringan teroris.

Kedua, budaya kekerasan yang tumbuh di sebuah Negara dapat menjadi salah satu motif terorisme. Hal itu disebabkan munculnya kesadaran kolektif bahwa kekerasan adalah tradisi, warisan sejarah, dan fakta sosial. Ketiga, terorisme meluas secara intensif karena tidak ada komitmen pemerintah untuk benar-benar melawan terorisme. Artinya, perlawanan atas terorisme hanya kebohongan. Kerja keras untuk membatasi gerak teroris dan menjamin tersedianya keamanan cenderung dinomorduakan. Karena itu, pemerintahan yang lamban, lembek, dan peragu memberi peluang bagi teroris melancarkan aksinya.

Keempat, terorisme adalah akumulasi penindasan, peminggiran, dan penderitaan. Mereka yang didiskriminasikan secara konstitusional dan tidak mendapat kebebasan sebagaimana kebanyakan masyarakat, biasanya menjadi faktor determinan meluasnya terorisme. Semula, para teroris berasal dari kelompok minoritas yang terpinggirkan, tetapi akhirnya membentuk kelompok yang bisa menjadi mayoritas. ${ }^{19}$

Sejumlah motif itu dijadikan referensi untuk melihat munculnya aksi terorisme dalam lima tahun terakhir. Gencarnya pembangunan Mal di sejumlah daerah dan terabaikannya kelompok miskin; hilangnya harapan untuk hidup sejahtera; hilangnya sensitivitas elite atas nasib

19 http://www.islamemansipatoris.com., n.d., diakses 30 Januari 2017. 
warganya; meluasnya kekerasan dan konflik, dan lain-lain merupakan faktor yang bisa menyuburkan terorisme.

Memandang terorisme tidak hanya saat terjadinya bom, tetapi dapat melihat sejumlah faktor internal dan eksternal jauh ke belakang dan ke depan. Utamanya, pemerintahan yang mendapat legitimasi politik secara demokratis harus memainkan peran semestinya dalam menyejahterakan rakyat, menjamin keamanan, dan memotong mata rantai terorisme.secara umum motiv terorisme di Indonesia meliputi tiga bentu

\section{Motif Politik Terorisme di Indonesia.}

Terorisme bukanlah tindak kriminal biasa, seperti kejahatan-kejahatan lain, sebagaimana kesimpulan hukum selama ini yang menyatakan bahwa terorisme merupakan kejahatan luar biasa (Exstra Ordinary Crime).

Menganggap terorisme terutama yang melanda Indonesia lima tahun terakhir hanya sebagai tindakan kriminal atau kejahatan luar biasa (Exstra Ordinary Crime) merupakan sikap dan pandangan yang tidak komprehensip dan terkesan terburu-buru. Sikap dan pandangan yang demikian pada gilirannya akan menimbulkan kesalahan dalam usaha penanggulangan terorisme sendiri. Untuk menghindari kekeliruan yang berakibat fatal terhadap kemungkinan-kemungkinan terjadinya tindak terorisme, perlu ditelusuri motif-motif "terorisme" yang melanda Indonesia.

Bila dilihat dari terorganisasinya dan sasarannya, berupa tempat hiburan yang sering dikunjungi warga Amerika Serikat, motif dibalik pengeboman bukanlah ekonomi, akan tetapi politik yang bersifat mondial. Para pelaku mempunyai tujuan tersendiri dan menginginkan sesuatu dengan pengeboman tersebut. Kejadian itu oleh para pelaku dijadikan peristiwa perang, dan merupakan bagian strategi perang global (global war). Dalam konteks ini 
Indonesia secara teoritis masuk dalam kategori extended territory, yaitu wilayah yang dijadikan ajang perang fisik guna menaklukkan musuh utama yang secara geologis keberadaannya relatif jauh. ${ }^{20}$

Terorisme di Indonesia pada dasarnya bukan merupakan karakter bangsa Indonesia, tetapi lebih merupakan konflik politik yang menggunakan agama dan memamfaatkan orang-orang beriman. Aksi-aksi "terorisme" di Indonesia yang melibatkan sebagian kelompok Umat Islam secara geneologis memperlihatkan motif politik yang sangat kuat.

Motif politik aksi "terorisme" di Indonesia tidak hanya bersifat nasional akan tetapi berskala internasional. Dengan pengertian lain bahwa "terorisme" yang melanda Indonesia bermotifkan "nasionalisasi konflik politik internasional antara Barat dan Islam". Adalah Imam Samudra salah seorang pelaku peledakan bom Bali I yang menegaskan bahwa peledakan bom di Bali merupakan bukti adanya konflik politik antara Barat dan dunia Islam. Berdasarkan pengakuan Imam samudra tersebut, maka sebenarnya peledakan bom di Bali 12 Oktober 2002 dan peledakanpeledakan lainnya dijadikan arena antagonisme politik oleh para "teroris" yang secara sadar tidak mempertimbangkan letak geografis Negara tertentu.

Konflik politik antara Barat dan dunia Islam atau lebih tepatnya kehancuran dunia Islam mencapai puncaknya ketika kekhalifahan Turki Usmani runtuh pada 23 Mei 1924. Seiring dengan hancurnya benteng terakhir kekhalifahan Islamiyyah di Turki, umat Islam tercerai berai dan terpecah belah menjadi Negara-negara nasional yang diinspirasi kebangkitan nasionalisme Eropa. Akibatnya terjadi perselisihan bahkan peperangan diantara Negara-negara

${ }^{20}$ Tb.Ronny Rahman Nitibaskara, "Bom Bali Jilid II," Kompas, 3 Oktober 2005. 
Islam sendiri yang sengaja dibikin oleh Amerika Serikat dan Israel. Contoh paling nyata adalah konflik politik antara Irak-Kuwait-Arab Saudi yang disutradarai Amerika Serikat. Dengan licik Amerika Serikat mengatakan bahwa Irak akan mencaplok ladang minyak Kuwait dan akan menganeksasi Arab Saudi. Selanjutnya Amerika Serikat menawarkan bantuan berupa pengiriman pasukan militer ke area konflik untuk menjaga keamanan teluk. ${ }^{21}$

Puncak dari drama kolosal yang sedang dipentaskan oleh Amerika Serikat adalah didudukinya Haramain-kota Mekah dan Madinah- dua kota yang sangat disucikan oleh kaum muslimin di seluruh dunia, oleh tentara Amerika Serikat. Kenyataan ini membuat sebagian ulama dan kaum muslimin marah besar karena pemerintah Saudi Arabia tidak menggubris peringatan mereka agar menolak kedatangan pasukan Amerika Serikat di Mekah dan Madinah. Padahal sebelumnya para ulama ini telah menawarkan diri dan menyatakan kesediaan mereka untuk menjaga Haramain.

\section{Motif Agama Terorisme di Indonesia.}

Motif lain dari semua peledakan bom dan aksi "terorisme" di Indonesia adalah bermotifkan sentimen agama. Motif agama ini lebih dominan ketimbang motimotif yang lain. Agama telah menjadi pemicu utama terjadinya berbagai aksi "terorisme" yang memporakporandakan Indonesia selama lima tahun terakhir. Memang agama sebagaimana pendapat Mark Jurgensmeyer seringkali dijadikan justifikator dan motivator tindakantindakan kekerasan teror. Yang paling mengkawatirkan para "teroris" menggunakan terminologi jihad dalam setiap peledakan bom yang mereka lakukan.

${ }^{21}$ Ibid., 91-92. 
Kata kunci yang selalu digunakan oleh para "teroris" dalam pelaksanaan peledakan bom dan setiap operasinya adalah kata jihad. Sebuah kata yang dikalangan Islam sendiri masih mengundang perdebatan. Kata jihad oleh para "teroris" ditafsirkan sebagai peperangan melawan kaum kafir yang memerangi Islam dan kaum muslimin. Pengertian ini terkenal dengan sebutan jihad fi sabilillah. Perjuangan yang menuntut pengorbanan untuk menegakkan agama Allah. Kata jihad memang sangat ampuh dalam membangkitkan semangat pemuda-pemuda muslim untuk ambil bagian dalam perjuangan menegakkan agama Allah, apalagi jika agama Allah telah dihinakan dan banyak terjadi pembantaian terhadap saudara mereka sesama Muslim. Menurut mereka umat Islam saat ini mempunyai dua pilihan; hidup ditengah-tengah penghinaan dan penderitaan; atau mati syahid dalam jihad fi sabilillah?

Perlu dikatakan di sini bahwa aksi "terorisme" yang terjadi di Indonesia ditujukan sebagai perlawanan, pembelaan dan pembalasan terhadap penghinaan dan pembantaian yang dilakukan Amerika Serikat dan Israel atas Islam dan kaum muslimin di Afghanistan dan Palestina. Selama Amerika Serikat dan Israel tidak menghentikan aksi brutal mereka terhadap kaum muslimin selama itu pula aksi balasan para "teroris" akan tetap berlangsung. Bahwa "terorisme" di Indonesia adalah sebagai reaksi pembalasan terhadap agresi Amerika Serikat dan Israel terhadap Afghanistan dan Palestina terlukis dengan jelas di bait-bait puisi Imam Samudra:

Tangismu wahai bayi-bayi tanpa kepala...dibentur di tembok-tembok Palestina...jeritmu wahai bayi-bayi Afghanistan...yang memanggil-manggilku tanpa lengan...dieksekusi bom-bom jahanam...milik setan Amerika dan Sekutu...saat ayah bundamu menjalani Ramadhan!! 
Ini aku, saudaramu...ini aku, datang dengan secuil bombing...kan kubalaskan sakit hatimu...kan kubalaskan darah-darahmu...darah dengan darah...nyawa dengan nyawa...qishash!!!

Kalaupun aksi pembalasan itu dilakukan di Bali atau daerah lain di Indonesia, tidak langsung di Amerika atau Israel, itu dikarenakan pemahaman mereka tentang jihad yang bisa dilaksanakan di mana saja dan karena Bali merupakan tempat berkumpulnya orang-orang Amerika dan sekutunya. ${ }^{22}$

Bahwa jihad bisa dilakukan kapanpun dan di manapun sangat terkait dengan strategi para "teroris" tentang perang global (global war) antara Islam dan orang-orang atau kelompok-kelompok yang memerangi Islam dan kaum muslimin. Orang-orang atau kelompok-kelompok yang dimaksudkan oleh para "teroris" adalah Nasrani dan Yahudi atau salibis Amerika dan Zionis Israel. Tidak tanggung-tanggung para teroris menyebutnya sebagai perang Salib.

Keyakinan para "teroris" bahwa kaum muslimin sekarang sedang mengalami perang Salib didorong oleh kesalahan-kesalahan yang dilakukan oleh Amerika Serikat dan Sekutunya dalam operasi-operasi militer mereka ke Afghanistan yang menggunakan istilah-istilah perang Salib.

Bush pada awalnya menggunakan sandi Crussade (Perang Salib) dalam agresi ke Afghanistan. Namun setelah mendapat kritik dari dunia Islam Bush mengganti dengan Operation Infinite Justice. Ternyata setelah ditelusuri Scott Rosenberg, istilah Infiniti Justice ternyata juga berasal dari terminologi Kristen yang ujung-ujungnya kembali kepada

22 Ibid., 103-10. 
"Perang Salib". Yang terakhir istilah yang digunakan adalah Operation Enduring Freedom. ${ }^{23}$

\section{Motif Ideologis Terorisme di Indonesia.}

Pasca Perang Dunia II berakhir, dunia terbagi ke dalam dua blok, blok kapitalis Amerika Serikat dan blok sosialis Uni Soviet. Terjadi Perang Dingin antara kedua Negara ini. Pada era ini terjadi perlombaan persenjataan, perebutan pengaruh ideologi dan peningkatan fungsi intelijen. Di era Perang Dingin ini, Amerika Serikat berusaha mendapat simpati Negara-negara Islam dan kelompok-kelompok Islam di dunia untuk berada di pihak mereka.

Kepandaian kaum kapitalis pimpinan Amerika Serikat dalam menganalisa dan mempengaruhi berbagai aliran Islam dan kelompok-kelompok Islam- yang secara tegas menentang ideologi komunis- memberikan keleluasaan kepada kaum kapitalis liberal untuk memperalat umat Islam dan Negara-negara Islam sebagai ujung tombak melawan kaum komunis. ${ }^{24}$

Kelihaian Amerika Serikat dalam upaya menghancurkan komunisme juga terlihat ketika Uni Soviet menginvasi Afghanistan. Amerika Serikat dengan suka rela membantu Afghanistan melawan Soviet dalam perang yang berlangsung selama 10 tahun (1979-1989). Hingga Uni Soviet runtuh. Dengan runtuhnya Soviet dunia berubah dari bipolar menjadi unipolar. Di masa ini terjadi transformasi radikal dalam tata hubungan antara TimurBarat dan Barat-Islam.

Untuk semakin memantapkan dominasinya atas seluruh dunia, membuat Amerika Serikat memutar otak mencari cara yang paling efisien dan efektif sebagai alat

${ }^{23}$ Ibid., 113.

${ }^{24}$ Munarman, "Perang Ideologi dan Terorisme," Republika, 9 Desember 2005. 
kendali terhadap dominasinya. Demi ambisi politik ini Amerika Serikat menempuh metode propaganda.

\section{Simpulan}

Terorisme merupakan kajahatan kemanusiaan yang sangat bertentangangan dengan nilai-nilai kemanusian yang sesungguhnya. Apakah itu hukum budaya, idiologi, sistem politik maupun agama. Setidaknya terdapat tiga bentuk motif yang bisa mereproduksi terorisme selama ini. Pertama, motif politik aksi terorisme di Indonesia. Motif ini tidak hanya bersifat nasional akan tetapi berskala internasional. Dengan pengertian lain bahwa terorisme yang melanda Indonesia bermotifkan nasionalisasi konflik politik internasional antara dunia Barat dan dengan dunia Islam.

Kedua, motif agama terorisme di Indonesia. Motif lain dari semua peledakan bom dan aksi terorisme di Indonesia adalah bermotifkan sentimen agama. Motif agama ini lebih dominan ketimbang moti-motif yang lain. Agama telah direduksi menjadi pemicu utama terjadinya berbagai aksi terorisme di Indonesia. Agama seringkali dijadikan justifikasi dan legitimasi tindakan-tindakan terorisme. Dan yang paling sublim para teroris menggunakan terminologi jihad dalam setiap peledakan bom yang mereka lakukan.

Ketiga motif ideologis terorisme di Indonesia. Sifat legal-formal ditunjukkan dengan kecenderungan menampilkan agama serba tekstual. Sifat doktriner ditunjukkan dengan mempraktekkan Islam serba mutlak dan kaku, sehingga menolak cara-cara penafsiran lain yang bersifat kontekstual. Hal ini membuat gagasan demokrasi, liberalisme, sosialisme, sekulerisme, dan ideologi lainnya diklaim sebagai doktrin "sistem kufur".

Karena itu, beberapa motif terorisme menjadi penting dikemukakan agar mendapat perhatian serius pelbagai pihak. Gencarnya pembangunan Mal di sejumlah daerah 
dan terabaikannya kelompok miskin, terjadinya jurang yang lebar antara orang kaya dan orang miskin, tidak terpenuhinya hak-hak masyarakat, hilangnya sensitivitas elite atas nasib warganya, orientasi pembangunan yang hanya mengedepankan aspek fisik, kurang memperhatikan aspek ruhani dan nilai-nilai sosial-keagamaan masyarakat, meluasnya kekerasan dan konflik, dan lain-lain merupakan faktor yang bisa menyuburkan terorisme[.]

\section{REFERENSI}

Abegebriel, A. Maftuh. "'Ada Apa Dengan Dokumen JI? Sebuah Penghampiran Hermeneutik.'” In Negara Tuhan The Thematic Encyclopaedia, diedit oleh A. Maftuh Abegebriel. Jogjakarta: SR-Ins Publishing, 2004.

Amstrong, Karen. Berperang Demi Tuhan, Fundamentalisme, dalam Islam, Kristen dan Yahudi. Jakarta: Serambi Ilmu Semesta, 2002.

Azra, Azyumardi. Konflik baru Antar peradaban Globalisasi, Radikalisme dan Pluralitas. Jakarta: PT Raja Grafindo Persada, 2002.

- - -. Pergolakan politik Islam: Dari fundamentalisme, modernisme hingga post-modernisme. Jakarta:

Paramadina, 1996.

Azyumardi Azra. "Gerakan Islam Militan di Asia Tenggara: Identitas atau Tantangan." Jurnal CSIS Vol. 33, no. 1 (Maret 2014).

Chomsky, Noam. Menguak Tabir Terorisme Internasional. Diterjemahkan oleh Hamid Basyaib. Bandung: Mizan, 1991.

Hakim, Lugman. Terorisme di Indonesia. Surakarta: Forum Studi Islam Surakarta, 2004.

Hardiman, Francisco Budi. Terorisme: Definisi, Aksi dan Regulasi. Jakarta: Imparsial, 2005. 
Husaini, Adian. Jihad Osama Versus Amerika. Jakarta: Gema Insani Press, 2001.

Juergensmeyer, Mark. Terorisme Para Pembela Agama.

Diterjemahkan oleh Amien Rozany Pane. Yogyakarta:

Tarawang Press, 2003.

Laqueur. New Terrorism Fanatisme dan Senjata Pemusnah

Massa (terj) Toni Febriyanto. Diterjemahkan oleh Toni

Febriyanto. Yogyakarta: Juxtapose, 2005.

Mahajan, Rahul. Perang Salib Baru: Amerika Melawan

Terorisme atau Islam. Diterjemahkan oleh Zaimul Am.

Jakarta: Serambi Ilmu Semesta, 2002.

Munarman. "Perang Ideologi dan Terorisme." Republika, 9 Desember 2005.

Muzaffar, Chandra. Muslim, dialog, dan teror. Jakarta: Profetik, 2003.

Rahman Nitibaskara, Tb.Ronny. "Bom Bali Jilid II." Kompas, 3 Oktober 2005.

Tandang Assegaf, Nurcahaya. Terorisme Internasional Bentukan Amerika Indonesia dan Dinamika Internasional. Jogjakarta: Ombak, 2004.

Thontowi, Jawahir. Islam Neo-Imperialisme dan Terorisme Perspektif Hukum Internasional dan Nasional. Jogjakarta: UII Press, 2004.

Wahid dkk, Abdul. Kejahatan Terorisme Perspektif Agama, HAM dan Hukum. Bandung: PT. Refika Aditama, 2004. http://www.islamemansipatoris.com., n.d. Diakses 30 Januari 2017. 
